\title{
The Development of Hispanitas in Spanish \\ Sixteenth-Century Versions of the Fall of Numancia
}

RACHEL

SCHMIDT

Summary: The story of the Celtiberian town of Numancia and its fall in 133 B.C., as seen in the writings of Livy, Plutarch and others, was a wellestablished topos in sixteenth-century Spain. The accounts of the bravery of the Numantians in defending their besieged city formed the basis for hispanitas, the gradual construction of a Spanish national identity. This paper examines the circulation of the tale of Numancia in four writers of the period: Antonio Guevara, Ambrosio de Morales, Fernando de Herrera, and Miguel de Cervantes.

A fter decades of intermittent battle with the Romans and months of a final A siege organized by Scipio Africanus (thereafter Numantinus), the Celtiberian town of Numancia, located near what is now Soria, fell in 133 B.C. Although prisoners were taken, ancient and early modern writers alike praised the once prosperous community of 8,000 inhabitants for choosing to destroy itself rather than yield its people and riches to its conquerors. The various tales illustrating the bravery and daring of the few Numantians (3,000-4,000 men) against the many Romans (as many as 50,000 troops) earned the city fame and respect already in ancient times, as seen in the writings of Livy, Plutarch and many others. ${ }^{1}$ In spite of reports of cannibalism and the homicide of some members of Numancia, in all these accounts the valor and sacrifice of the Celtiberians stand in contrast to the cowardice and decadence of the Romans. Only Scipio merits praise among the Romans in this ignominious tale, for he alone evinces the military strength of will and character necessary to discipline his lascivious and timid troops and subjugate the fierce barbarians. In an ironic twist of fate recognized by the Roman historians, the barbarous Numantians, unlike their unworthy conquerors, achieve fame by representing Roman 
imperial values in their willingness to die for their patria. ${ }^{2}$

By the sixteenth century, the tale of Numancia circulated throughout Spain in the writings of Antonio Guevara, Ambrosio de Morales, Fernando de Herrera, and Miguel de Cervantes as an example of the conflict between individual and communal interests, particularly with respect to the valor and bravery of the Spanish people conceived of as hispanitas. Antonio Guevara, the Bishop of Mondoñedo and Charles V's official chronicler, recounted the tale in the first volume of his Epistolas familiares (1539) as a moral exemplum unrelated to any specific characterization of national character. For Guevara, the city's antagonist, the Roman commander Scipio, stood out as a bad example of the evil effects of obstinacy in a man of war, which resulted in barbaric reactions by the Numantians. It was left to Ambrosio de Morales, a historian in the court of Philip II, to depict the city of Numancia as the protagonist of the account in his continuation of Florian Ocampo's Corónica general de España (1574), an officially sanctioned history of Spain. Morales' narration exemplified the use of the tale to describe a Spanish character, or "natural" in his own words, in order to promulgate a national identity based upon the military values of bravery, self-sacrifice, and virile strength, undermined only by a propensity to divisiveness. The Sevillian poet Fernando de Herrera revealed in off-hand allusions to the tale in his commentaries on the poetry of Garcilaso de la Vega (1580) the extent to which these values pervaded his concept of literary value. The poet, like the Numantian, served his patria through the defense of its fama. Yet Miguel Cervantes de Saavedra, a man of arms and letters, cast light upon the intellectual contradictions and tensions implicit in the application of the Numantian example to sixteenthcentury Spain in his dramatic representation of the episode, La Numancia. When placed within the historical narrative of an Iberia perceived as a continuous community from pre-Roman times to the sixteenth century, the Numancia tale clearly provided teleological justification for the Hapsburgian unification of the peninsula and imperial undertakings in Italy. Yet, as the tensions of Cervantes' play revealed, the Roman values of patriotic service to the empire never comfortably aligned with the values of a nation that also proclaimed itself the defender of Catholic orthodoxy.

\section{Guevara's Account: The Moral of the Story}

In Letter 5 of his first book of the Epistolas familiares, Antonio de Guevara relates the siege and fall of Numancia in reply to an argument between Alonso Manrique, Archbishop of Sevilla, and Antonio Manrique, Duke of Nájera, 
concerning the site of the Celtiberian town. Although Guevara correcty asserts it to have been near modern Soria, the settling of the dispute merely provides him with an excuse to recount the entire story as a moralistic tale. Scolding the two noblemen for having entered so stubbornly into the dispute, he reprimands them for having violated the dignity of their own status as hidalgos. For this sixteenth-century Spaniard, the social caste of the noble is still that of the warrior. "Al caballero que es animoso, esforçado y valeroso, nunca se le ha de encender la cólera, si no fuere en desenvainando la espada, porque muy poquitas veces sale esforçado el caballero que es muy parlero." 3 The warrior is a man of action, not words, who, unlike the philosopher, cannot indulge in anger or dispute because his weapon, the sword, could cause unjust bloodshed.

For Guevara, the tale of Numancia is essentially that of Scipio's uncompromising obstinacy and the violent havoc it brings about in the Celtiberian community. The Numantians remain undifferentiated and unnamed, a collective that lived in a society unblemished by commerce and greed, which would have served to introduce distinction among them. The blacksmith was the city's only official, and even in war the community acted as one. Tradesmen and skilled craftspeople were not allowed to reside in the city in order that the inhabitants would remain self-sufficient, each household providing for all its own needs. The resulting communal ethos discouraged personal gains and encouraged the defense of the city-state. In his description of the Numantians, Guevara implies that even honor was a communal rather than personal concern: "de hazienda eran poco cobdiciosos, y de honra muy ambiciosos." 4 Clearly, Numancia represents a utopia, in which the interests of the group and the individual coincide to create a self-sufficient community. As such, Numancia fulfills the Medieval ideal of the city-state (albeit stripped of its mercantilist dimension), which, "in a world that was very fragmented and dangerous, these havens of human intercourse, peaceful activities and relative abundance seemed models of 'good government' [and] inspired the enthusiastic adherence of their citizens and inhabitants." 5

In Guevara's account of the fall of the unified city, Scipio stands out against the backdrop of the Roman imperial army as a lone distinguished individual. Like the Roman historians, Guevara presents the commander as the catalyst for the dénouement of the decades-long standoff. He repeats the Latin reports of Scipio's cleansing of the Roman encampment and restoration of military disciplines. But Guevara also emphasizes the military leader's refusal to engage the Numantians in open battle. Scipio repeatedly responds to pleas from both his own officers and the besieged inhabitants themselves that " $[\mathrm{e}] \mathrm{s}$ 
tan fortunada Numancia ... que se ha de acabar, mas no esperar que se ha de vencer." ${ }^{\prime \prime}$ The Roman general recognizes the city as invincible, and chooses to finish them off rather than defeat them, a decision which could appear rational in the light of the Numantians' success in earlier skirmishes with the Roman army. In an anecdote found to my knowledge only in Guevara's account, however, Scipio's stubborn refusal to quit the siege and return to Rome is explained by the prophesy of a necromancer: “. . . al salir de Roma le había dicho un sacerdote nigromántico que no desmayase ni se retirase de aquella conquista, dado caso que pasasen inmensos peligros en ella, porque los dioses tenían determinada que el fin de la fortunada Numancia había de ser el principio de toda su gloria." Thus, the community's defeat becomes intimately linked to the individual commander's glory. Numantian communal honor is to be sacrificed for Scipio's personal gain.

The Roman's stubborn ambition for individual glory sets into motion the degradation of Numancia into cannibalism and homicide. Guevara does not flinch from repeating the ancient reports of cannibalism of Roman soldiers by the Celtiberians, but rather explains this "cosa monstruosa" as a result of the extreme hunger caused by the siege. Both the Numantians and Romans are subsequently dehumanized into predator and prey.

Cosa monstruosa fué entonces de ver, como lo es agora de oír, que ansí andaban los numantinos cada día a caça de romanos, como los caçadores a oxeo de conejos, y tan sin asco comían y bebían de la carne y sangre de los. enemigos, como si fueran espaldas y lomos de carneros. Grandísimo era el daño que cada día rescebía el cónsul Scipión en aquel cerco, porque los numantinos, allende de que como fieros animales andaban en los romanos encarniçados, peleaban ya, no como enemigos, sino como desesperados. ${ }^{8}$

Scipio's obstinacy, then, causes the dehumanization of the proud Numantians, converted into desperate animals, and the destruction of his own troops, transformed into rabbits, the enemies' fodder. The final plea for Scipio to desist comes from the Numantians, who beg for an honorable battle. Speaking as a group, they appeal to the Roman commander's thirst for glory, “. . tapiarnos como nos tienes tapiados no es más de un buen ardid de guerra; mas si nos vencieses en batalla sería para ti una inmortal gloria." Their collective suicide follows, a "cosa espantable," depriving Scipio of loot or prisoners. In a final statement Scipio, overwhelmed by sadness, repeats the fortune of Numancia - that it would be ended, but never defeated.

Guevara's account of the historical event is, in fact, an exemplary tale of the destructive impact of greed, obstinacy, and envy, perceived as individual 
faults, on the honor of a community. Whereas the destruction of Numancia does earn glory for Scipio, it is a glory tainted by dishonor to Rome. According to Guevara, all the historians claim that Rome never suffered such an affront or lost so many troops as in the conquest of Numancia. The explanation provided for this dishonor is that "todas las otras guerras iban fundadas sobre alguna injuria, excepto la de Numancia, que fué de pura envidia."10 The envy to which Guevara refers, of course, is Scipio's ambition for the fame and glory enjoyed by Numancia. As recounted by Guevara, the tale of the fall of Numancia becomes the story of the moral downfall of Scipio, and serves as a negative example of the destructive power of stubbornness and ambition for personal glory in a man of war. The reference to the dispute between the two nobles concerning the site of Numancia functions, then, as a frame for the moralizing tale, a technique common to Medieval prose, seen, for example, in Don Juan Manuel's El Conde Lucanor. Significantly, Guevara does not attribute the injustice suffered by the Celtiberians to Roman imperial interests, but personalizes the error in Scipio's individual character flaws of obstinacy and envy. ${ }^{11}$ Nonetheless, he does highlight both the communal honor of Numancia and its final triumph, expressed ironically through Scipio, who acknowledges the community's invincibility. It is left to Ambrosio de Morales, another court historian, to develop Numancia's resistance into a tale illustrating Spanish national honor.

\section{Morales' Account: “Our” Numantians}

Although the story of Numancia had already appeared in Antonio Guevara's Epistolas familiares and was known to a more popular audience through romances, the account that appears to have been definitive for both Herrera and Cervantes comes from Ambrosio de Morales' continuation of the Corónica general de España, an officially sanctioned history of Spain started by Florian Ocampo. ${ }^{12}$ As such, Morales' presentation of the clash between the Romans and the Celtiberians at the end of the second century B.C. reflects many interests of sixteenth-century Hapsburg Spain, in particular those surrounding Iberian unification and imperial expansion. The sense of a Spanish patria that contributes to and is strengthened by these changes serves as a foundation for Morales' historiographical undertaking to continue Florian Ocampo's history of Spain. As José Antonio Maravall has shown, in the thirteenth century both Castilian and Aragonese historians began to conceive of Spain as "una entidad humana asentada en un territorio que la define y caracteriza y a la cual le sucede 
algo en común, toda una historia propria."13 Thus, the concept of Spain as the collective of Iberian inhabitants had already developed in the late Middle Ages. As John Elliott has observed, the use of the word patria became ever more widespread in the sixteenth century, promulgated by the humanistic study of Greece and Rome as political models, and a new interest in the historical heritage and legal constitutions of states which combined to foster a sense of a community broader than one's hometown..$^{14}$ Accordingly, in sixteenth-century Spain, Ambrosio de Morales could claim the Numantian episode as a founding moment in the history of his patria replete with the tones and weight of mythology.

Morales' unquestioned identification of the Numantians as Spaniards is probably the most significant of his interpretive stances. The opening sentence of the eighth book of the history announces unequivocally that: "[l]lega ya aquí la Historia de España a lo más alto de gloria y fama que en estos tiempos pudo subir: pues se ha de comenzar a escribir la guerra de los Romanos con nuestros Numantinos. .."15 Temporal distance and cultural difference are obviated as Morales stakes claim to Numancia for his Spanish history. Nor should we suspect that Morales was unaware of the historical conflation he was undertaking in his identification of a Celtiberian city-state with the nation Spain, itself only born at the end of the fifteenth century when Ferdinand and Isabella united their reigns and defeated the Moorish kingdom of Granada. The historian uses the terms "Celtiberia" and "Celtíberos" when he writes of other communities on the peninsula, but never with reference to Numancia. At times he does apply the term "Español" to these other towns and peoples, but always with his own concept of a generalized Spanish character in mind. For example, he contrasts the ingenuousness of Palencians, duped by enemy claims that their city had been overrun, with the deceitfulness of the Romans. ${ }^{16}$ Thus, Morales begins to compile a list of attributes of the Spanish character, in this case that of fatefully innocent sincerity, which are best exemplified by Numancia.

This identification of the Spanish nation with the earlier inhabitants of Iberia, despite the complete discontinuity of religion, language, and society between the two cultures, should not be seen as either naive or manipulative. Rather, Morales bases this historical conflation on the medieval Latin concept of universitas, "a conjunct or collection in one body of a plurality of persons," that confer legislative power, imperium, on their government. ${ }^{17}$ Universitas itself arose from the Roman legal concept of lex regia, which established "the imprescriptible right of the Roman people to confer the imperium and all power on the Prince." 18 The community existed legally as an entity which itself 
bestowed legitimacy on a given government, and persisted regardless of specific political affiliations in given historical epochs. In the Middle Ages jurists began to acknowledge the rex legia of various peoples since Rome itself had fallen, and thus the translatio imperii became a legal reality. In turn, the community represented by universitas expanded temporally to include all inhabitants of a given place throughout time, in our case Iberia, and enjoyed the sempiternal quality of the Church and the Roman empire. According to Kantorowicz, this attribution of a timeless quality to a community creates a third, legally recognized being which, immaterial and unchanging, represented the community through all time as a distinct species which expressed itself in the individual. ${ }^{19}$ Thus, if one, like Morales, recognizes Spain as a sempiternal universitas, one can speak of hispanitas, or Spanishness, a character which is at once generic to all Spaniards and present in individuals.

The Numantians, therefore, as members of the Spanish universitas, represent the Spanish character at its finest. According to Morales' representation of the Numantians, hispanitas encompasses valor, competitiveness, and a fierce love of liberty. During a day of festivity before Scipio's siege, a Numantian father, "con respecto y pensamiento de verdadero Español y Numantino," demanded that two young men competing for his daughter bring back the right hand of a Roman to win hers. ${ }^{20}$ The two young men, "encendidos con el amor y competencia," rushed out to do so, only to find that the Roman troops had already fled from fear by cover of night. ${ }^{21}$ Thus, a small domestic episode illustrates the essential qualities of "los nuestros" which made possible resistance against Rome. Nor is this essentially brave and fierce hispanitas restricted to the males. Writing of the Galician resistance to Junius Brutus, Morales notes that the women fought alongside the men, "[p]orque siempre el esfuerzo Español, no era sólo de los hombres, sino que también se hallaba muestra notable de él en las mujeres." 22 The overriding character of hispanitas erases any differentiation between private and public conduct, or the behavior of women and men. Morales points out that the "Portugueses de Braga" also brought their women to battle, who, when they were taken captive, killed themselves and their children, rather than see them taken captive. ${ }^{23} \mathrm{~A}$ precedent was set for the infanticide practiced in Numancia as an expression of this love of liberty - and done so by Lusitanians, who are clearly perceived by Morales as part of the universitas in question. ${ }^{24}$ The collective suicide of Numancia was not, then, an aberration, a transient madness, or a sin, but the fulfillment of Spanish character when faced by the loss of liberty.

Nonetheless, hispanitas as conceived by Morales has a darker face which 
also contributes to the fall of Numancia - the love of contention and disunity. Morales asserts that not only did other Iberians fail to come to the aid of Numancia, but that many sent troops to the Romans, "[p]orque siempre parece que no podían ser vencidos los Españoles, sin que Españoles ayudasen a vencerlos." ${ }^{25}$ Writing of the betrayal of Malia by its own citizens to Pompey, the historian exclaims with a tone of exasperation:

\begin{abstract}
¿Cómo habíamos de vencer los Españoles a los Romanos, siendo nosotros mismos los que procurabamos nuestra destruición? Nuestras discordias y particulares enemistades, y aquella inclinación natural de todos los Españoles a ver novedades, cansándose de estar siempre en un ser, aunque sea muy bueno, nos hacía la guerra, y nos quitaba de las manos la victoria de todos los Romanos, que sin duda la alcanzaramos con unión y concordia. ${ }^{26}$
\end{abstract}

The self-destruction of Numancia, abandoned by its fellow Iberians, represents in miniature the entire self-destruction of Hispania, fatally weakened by its own divisiveness. The ser, the timeless identity of the universitas, falls victim to the other side of its natural, as the individual Spaniards seek novelty and discord. Thus, Spain lost what would have been its finest prize, victory over the Romans.

Central to Morales' daring assertion that the Iberians could have defeated the Roman armies of such superlative generals as Pompey and Scipio Africanus are accounts related by various ancient historians of the fear inspired by the Numantians among the Roman troops. Morales generally uses his ancient sources to reinforce his vision of the Spanish natural, the hispanitas. In this case, the classical writers attest to the great valor of the Spaniards as warriors, who instill fear in the Roman troops. He quotes Lucius Florus, who reported that there was no Roman soldier who dared to hope for victory upon hearing or seeing a Numantian. Without advising the reader of his ruse, Morales also elaborates upon the words of Paulus Orosius, who stated that no Roman soldier could stand firm, considering himself defeated if he saw an "Español." ${ }^{27}$ That the Roman historians, clearly seen by Morales as involved in a nationalistic historiographical undertaking akin to his own, would denounce the cowardice of their own army to praise the bravery of their enemies is irrefutable proof of Numancia's glory and Spain's capacity for valor.

Y Lucio Floro, historiador natural de Roma, acabando así de contar el fin que tuvo esta ínclita ciudad, la celebra tanto, que dice estas mismas palabras. Dí buen testimonio de la gloria y esclarecido valor de Numancia, y de su gran esfuerzo, y de su dichosísima suerte entre tantos males y miserias, el haber mantenido tantos años la fe con sus aliados, y el haber sufrido tanto tiempo, 
y resistido al Pueblo Romano, que guerreaba con las fuerzas de todo el universo. ${ }^{28}$

Morales uses the Roman historian's words to provide a portrait of the most illustrious virtues of Spain as seen through the lens of Numancia - valor, strength, loyalty, perserverance despite suffering, and unending resistance to invasion. As Herrero García has shown, many of these same characteristics, such as sobriety, valor, excellence, and mutual censure, became commonplaces of Spanish identity by the seventeenth century. ${ }^{29}$

By the same token, an ancient source also verifies Spain's weakness, its tendency toward disunity. Morales ends his account of Numancia by citing the words of Strabon, who wrote with respect to the invasion of Iberia by the Carthaginians and Tyrians that the inhabitants would have been invincible, if they had been united among themselves in their defense. As Morales adds, "esto mismo que dice Strabon de estas dos naciones, se puede muy bien extender a la entrada de los Romanos en España." ${ }^{30}$ Morales also quotes an anecdote reported by Paulus Orosius, which sums up best the moral of the story of Numancia within a sixteenth-century nationalistic history. An old man, when asked by Scipio about the Numantian's invincibility, responded: "Con la concordia se mantuvo, y con la discordia pereció. Que tanto como esto puede destruir y asolar una desconformidad." ${ }^{\text {31 }}$ Morales has, however, put words into the fourth-century historian's mouth, who stated simply: "Concordia invicta, discordia exitio fuit." Paulus Orosius then proceeded to note that the Romans took this as an example of what was taking place in their own city at the time due to the Gracchian insurrection. ${ }^{32}$ Morales uses a similar tactic, of course, as one can easily infer that the dictum applies equally well to sixteenth-century Spain, but he voices his elaboration on the destructive power of disunity through the more authoritative mouth of an ancient source. Morales' two acts of "extending" the didactic message concerning Spain's vulnerability due to divisiveness, the one stated as he applies Strabon's words to the Roman invasion, the other fudged as he speaks through Paulus Orosius, surely invite the sixteenth-century reader to appreciate the unification of Spain achieved by Ferdinand and Isabella. ${ }^{33}$

\section{Herrera's Numancia: The Defense of Spanish Culture}

The concept of a Spanish universitas and a subsequent hispanitas revealed in Morales' account of the fall of Numancia enters into the defense of sixteenthcentury Spanish poetry and culture contained within the poet Herrera's 
commentaries on the works of Garcilaso de la Vega. In a gloss to a description of an "osado español y sobrado," who demands battle against the Turks (Eglogue II, v. 1539-1540), Herrera states that he wishes to digress here upon the ancient custom of the Italians, "inherited from the Romans," of vituperating against Spaniards. ${ }^{34}$ The poet's rage springs from the disparaging comments on Spanish culture made by Italians such as Bembo, Sabélico and the Marquis of Pescara. For Herrera, the dispute reeks of a family feud. "¿Qué razón permite que llamen Bembo y Sabélico bárbaros a los españoles, siendo de una religión, de unas letras y casi de una lengua?" 35 Herrera, of course, puts forth the proposition that "nunca faltan ni faltaron en España hombres doctos y de singular erudición y elocuencia por todas las edades." ${ }^{36}$ Nonetheless, in the very next sentence he begins to proclaim his nation's military glory. Thus, the poet enters into a very long digression composed of rhetorical questions championing the cause of Spain by highlighting the nation's heroes and valorous achievements.

Implicit in Herrera's harangue is the identification of Italy with Rome as one universitas and Spain with Roman Iberia as another. His complaint against Italy rests largely on the occupation of Iberia by Rome, which he perceives to have been of particular disadvantage to the peninsula since no other province gave so many riches and great men to the empire and received so little recognition. ${ }^{37}$ Of course, Numancia serves as the example par excellence of the mistreatment of these early Spaniards, an example which was recorded by the historians. Herrera describes the inferiority of the city, unprotected by walls and towers, small in size and numbers, and thus emphasizes the glory of their resistance. He echoes the words of Scipio in Guevara's account as he proclaims that the city succeeded: "[n] o fue vencida Numancia, sino muerta; no rota, sino acabada." 38 Whereas Scipio, the victor over Carthage, cannot overcome Numancia, hunger, steel, poison, fire, and their own hands do, "sin que bastase fuerza contraria para presumir esta honra." 39 Significantly, Herrera perceives the collective suicide of Numancia as an act which protects the city's honor, for he himself uses the case to defend the honor of Spanish culture.

Thus, the valor of the Celtiberians, lauded at the beginning of the outburst, is proof of Spanish bravery equal to that of Cortés, el Duque de Alba, and the other military leaders of the sixteenth century with whose examples Herrera concludes his argument. In his descriptions of the various heroes of Christian times, Herrera couples valor with faith and piety, as he praises the "valor. .., fe y piedad" of Teodosius, the "fortaleza y piedad" of Conde Fernán González, and the "ánimo y fe" of Don Diego Ordóñez..$^{40}$ The Spanish hispanitas expands 
to combine valor with religious fervor and constancy. In this manner, Herrera's defense of his nation, which he concludes with the rather grudging admission that Spain has not lacked heroes, but writers to memorialize them, demonstrates how the Numancia account operates within the sixteenth-century conception of Spain as the defender of Catholic orthodoxy and an imperial power. The city that chose suicide rather than enslavement represents the fierce, uncompromising strength of warriors, defeated ultimately not by the enemy but by their fellow Iberians's inability to join forces with them. "¿Pudiera Roma domar las rebeldes cervices de aquellos antiguos españoles, hórridos y feroces en la guerra, si quisieran conservar su libertad juntamente?"41 Now that the same ferocity is wed to piety and the peninsula is reunited, great things await the empire, already signalled for Herrera by the conquest of the Americas and the war with France. The poet Herrera joins in the imperial enterprise through his participation in the belated passing of letters, translatio studii, to the peninsula. As he concludes his revindication of his nation, in itself a miniature history of Spain, he writes: "[p]ues sabemos que no faltaron a España en algún tiempo varones heroicos; faltaron escritores cuerdos y sabios que los dedicasen con inmortal estilo a la eternidad de la memoria." ${ }^{42}$

\section{Cervantes' Numancia: The interplay of Justice and Honor}

Cervantes' early play La Numancia (ca. 1581-1585) commemorates in literature such national heroes, yet by so doing also demonstrates the difficult compromises with the actual material of the incident made by those who use the episode as an example of hispanitas. Critics have struggled with the obvious praise of the Spanish Hapsburg empire. J. B. Avalle-Arce argues that the play represents renovatio imperii, the renewal of the Roman empire, in sixteenth-century Spain through the subjugation of Rome ${ }^{43}$ On the other hand, Stanislav Zimic contends that the play rejects the Roman model as evil in favor of a new concept of empire based on concord and peace.$^{44}$ Marie Laffranque, in contrast, has argued that the sixteenth-century public, as well as Cervantes himself, would have identified with both the Romans and the Numantians. ${ }^{45}$ Turning now to Cervantes' La Numancia, I seek to show that the play reveals the contradictions inherent within the conceptual relationship between Rome and Numancia from the perspective of sixteenth-century Spain that complicate such issues as the transferral and imitation of the Roman empire.

As Ramón Menéndez Pidal observes, the Roman empire did serve as the model for the ideal society in early modern Europe. "Hacer de todos los 
hombres una familia, unidos por los dios, por la cultura, por el comercio, por los matrimonios y la sangre, fué la gran mision del imperio romano, ensalzada por los paganos desde Plinio hasta Galo Namaciano y por los cristianos a partir de los españoles Prudencio y Orosio y del africano San Agustín."46 Thus, the leaders of Hapsburg Spain, including both Charles V and Philip II, saw themselves as the new emperors. As Laffranque has noted, the Hapsburgs themselves encouraged their subjects to draw the parallel between their house and the emperors of Rome, as seen in the iconography of their residence in Innsbrück. ${ }^{47}$ Nevertheless, their concept of empire, as expressed by such advisors as Mota, was transformed by the Medieval understanding of universitas cristiana, a transcendent community which encompasses all of Christianity and forms the basis for the Holy Roman Empire. ${ }^{48}$ Spain's relationship to Rome became essentially ambivalent - on the one hand, Roman political values were to be imitated, but, on the other hand, transformed by Christian values and used to further the divine empire on earth.

Cervantes captures this ambivalence in his Numancia in an unwillingness to depict either the Romans or the Iberians as morally good or evil ${ }^{49}$ Scipio is an ambivalent character, as seen from Orosius on, for he embodies the values of the good soldier and leader in spite of his hard indifference to the pleas of the trapped Numantians. ${ }^{50}$ Cervantes' characterization of the Roman as a fierce, unyielding warrior parallels the image of hispanitas epitomized by the Numantians, in which the honor of the patria is proved by valorous action (I.65-80).$^{51}$ At the beginning of the play, Scipio's ire against the Numantians is fueled not by personal ambition, as in the case of Guevara's Scipio, but rather by the same ambition motivating the Celtiberians, the desire to protect the name and fame of the patria. As he harangues his troops, "¿Paréceos, hijos, que es gentil hazaña/que tiemble del romano nombre el mundo,/y que vosotros solos en España/le aniquiléis y echéis en el profundo?" (I.81-84). Scipio repeatedly links Roman national honor to deeds of war and the respected name of the empire, thus setting a standard for the good soldier, disinterested in personal gain, that he himself represents in Cervantes' play as a model leader. The Numantians demonstrate a parallel sense of communal honor in their own dedication to the invincible name of their community, and are praised reluctantly at the end by the Roman for their exemplification of the classical dictum, pro patria mori. The Roman invader cannot be simply viewed as evil, for his values have passed on, slightly transformed, to become the foundation for the emergent European nationalisms. Indeed, his empire has passed to the conquered land now turned conqueror. 
By the same token, the Numantians, although epitomizing the values of love of nation and bravery, are not exemplars of Christian virtues, but rather Roman Stoic virtues..$^{52}$ To commit suicide in order to escape from slavery as a prisoner of war, viewed positively by the Romans, was roundly condemned by saint Augustine, who proposes as a classical example of virtue the defeated military hero Regulus, who allowed himself to be humbled as a captive. ${ }^{53}$ Christian narrators of the tale were thus forced to recast Numancia's selfdestruction within a religious paradigm in order to "purify" the act. Augustine's disciple, Paulus Orosius, attempted to purify his praise of the Numantians by endowing them with the Christian virtues of faith and justice perceived as mercy, as well as strength, from whom the Romans could have learned a lesson..$^{54}$ The key episode for this interpretation of the encounter between the Romans and the Numantians concerns Mancinus, a Roman captain who had agreed to a secret peace pact with the Numantians, only to be left naked outside the gates of the enemy city as punishment decreed by the Roman Senate for having agreed to a dishonorable treaty. Morales quotes the ancient account: "Habíase de hacer prueba de misericordia: harto buen testimonio dieron los Numantinos de ella, dando primero la vida a todo el ejército de sus enemigos, y después no executando en Mancino la pena, a que aun los suyos le condenaban." 55 Cervantes omits the incident, perhaps in favor of a more unified temporal structure for his play, but in so doing sacrifices proof of the Numantian misericordia.

Cervantes, on the other hand, focuses on the dismemberment of the corporate body of Spain instead of the preservation of the individual body of Mancinus in an effort to present the episode within the conceptual framework of justice rather than mercy. Elements of Guevara's and Morales' representations of the fall of the Celtiberian city enter into Cervantes' drama to indict Scipio for his stubborn refusal to respond to the Numantian pleas for honorable battle and the Iberians for their disunity. Despite his positive portrayal of Scipio as the valorous and disciplined warrior defending his patria, Cervantes does share with Guevara his vision of the military commander's unseemly obstinacy. In the first act Scipio rejects the Numantian's offer of peace to him in recognition of his warrior virtues as an act of arrogance. In the second act he rejects their offer for open battle in an exchange that echoes Guevara's characterization of the Celtiberians as desperate animals and the Roman troops as their prey. After his troops continue to suffer losses, Scipio turns his rage against the enemy, dehumanizing the Numantians into wild beasts: "Bestias sois, y por tales encerradas/os tengo donde habéis de ser domadas" (II.1191- 
2). In response, the Numantian spokesman denounces the Romans as "cobardes" (II.1206) and "liebres en pieles fieras disfrazados" (II.1229).

The dehumanization of Numancia parallels the dismemberment of Spain personified as the matria. Appearing at the end of the first act crowned with towers and carrying a castle in her hand, she is the figure of Spain conflated with Castilla, reciting her sad history of disembowelment by the Phoenicians and Greeks in search of her riches (I.361-368). ${ }^{56} \mathrm{Her}$ occupation by the Romans is itself the result of the disunity of her own people: "Y ansí con sus discordias convidaron/los bárbaros de pechos codiciosos/a venir a entregarse en mis riquezas,/usando en mí y en ellos mil cruezas" (I.381-384). Thus, Cervantes incorporates the universitas linking Numantia to Hapsburgian Spain already seen in Morales' account, and inflicts upon her maternal body the wounds of division. As in Morales' tale, the ultimate cause of the selfdestruction of Numancia lies with Spain itself, having laid the motherland open to invasion because of the discord between its own members. The individual culpability of the warrior Scipio cedes before the communal fault of Iberia understood as the Spanish universitas.

With a twist of dramatic justice, the case for the rectification of the Numantian's self-destruction and the restoration of the matria's honor rests with the sixteenth-century Spaniards. The river Duero, a male personification, responds to her cries, addressing her as "Madre querida, España" (I.441), and prophesying the triumphs to come. Embodying Christian misericordia, sixteenth-century Spaniards will exercise mercy toward Rome, as Charles V's imperial troop spare the ancient city's inhabitants in the sack of Rome of 1527: "y también vendrá tiempo en que se mire/estar blandiendo el español cuchillo/ sobre el cuello romano, y que respire/sólo por la bondad de su caudillo" (I.489492). Accordingly, the Hapsburg empire does not only enjoy the turn of fortune foreseen by the Duero, in which the vanquished will be victors, but also earns the translatio imperii through its Christian conduct of empire. Thus, virtue counterbalances destiny, and casts a Christian teleology onto the transfer of imperial power to Spain. By the same token, she herself will be made whole again. The Duero prophesies both the christianization of Spain through the forced conversion of Moors and Jews and expulsion of resisters by Ferdinand and Isabella (I.503), and the unification of Portugal with Spain in 1580 by Philip II (I.517-520). Spain, significantly conceived of here as matria, will once again enjoy honor as a whole and united Christian universitas.

The conflation of national honor with personal honor manifested in the figure of Spain as a violated woman represents the merging of individual with 
communal interests, the conflict at the base of sixteenth-century Spanish accounts of Scipio's siege of Numancia. The only moral code that would allow the suicide and fratricide of the city other than the concept of pro patria mori is the honor code, so predominant in the comedia. Unlike the historians, who view the willingness of the women to die as either evidence of their love of country or their love for their husbands, Cervantes presents their pleas for death as attempts to avoid dishonor through being raped upon capture (II.12931302). Teógenes consecrates his act of infanticide by calling on the spilled blood of honor (III.2140-2143). And so the blood of families spilt by fathers and husbands to protect personal honor replaces the blood of soldiers to be spared by Scipio on the battlefield in defense of the national honor. By the same token, Cervantes figures the universitas Spain as the raped woman, invaded and dishonored by the many barbarians, taking advantage of the disunity between her children. Thus, private and public honor intersect in Cervantes' version of the fall of Numancia. Like Guevara's account, Cervantes' play highlights the destructive power of individual interest in contrast to the strength of the community. Like Morales, he reinforces the sixteenth-century conception of unyielding hispanitas weakened only by internal division. Just as Herrera ends his discussion of the Numancia episode with a cry for writers and artists to defend the national honor, Cervantes ends his play with the heroic cry of the small boy Bariato, dying for the patria. Yet, in the figure of the dishonored matria, the play also renders ambiguous the relationship of Spain to Rome as the inheritor of its oppressor's imperial ambitions and ideology.

University of Calgary

\section{Notes}

1. J. M. Blazquez and A. Tovar, Historia de la España romana (Madrid: Alianza, 1982) pp. $72-77$.

2. For a discussion of the Catholic appropriation of the classical dictum pro patria mori to the work of Christian martyrdom, which kept the value alive in the Middle Ages to be reasserted in terms of the state by Renaissance humanists, see Ernst H. Kantorowicz, The King's Two Bodies: A Study in Mediaeval Political Theology (Princeton: Princeton University Press, 1957), pp. 232-249.

3. Antonio de Guevara, Libro primero de las epístolas familiares, ed. José María de Cossío (Madrid: Biblioteca Selecta de Clásicos Españoles, 1952) p. 38.

4. Ibid., p. 41.

5. Yves-Marie Bercé, Revolt and Revolution in Early Modern Europe: An Essay on the History of Political Violence, trans. Joseph Bergin (New York: St. Martin's Press, 1987), p. 39. 
6. Guevara, p. 43.

7. Ibid., pp. 44-45.

8. Ibid., p. 44.

9. Ibid., p. 45.

10. Ibid., p. 47.

11. In a well-known excerpt from his work Libro áureo de Marco Aurelio (published in pirate editions in 1528), "El villano del Danubio," Guevara does criticize the Roman empire through the mouthpiece of a German peasant for having greedily stolen the goods of others, and hypocritically asserting that these conquered peoples needed the Roman rule of civilization (Biblioteca de autores españoles. Vol. 65. Madrid: Atlas, 1953) pp. 160-166. This same sage predicts that the gods will eventually turn the tables on the Romans, who will then suffer for their unjust deeds (162). Nonetheless, Guevara does not articulate the just reversal of Rome's fortune in the sixteenth century when faced by Spanish troops in his account of the Numancia episode.

12. Helmut Koenigsberger has described Ocampo's narration of the history of Celtiberian Spain as "a nationalistic historical fantasy" in his article "Spain," in National Consciousness, History, and Political Culture in Early-Modern Europe, ed. Orest Ranum (Baltimore: Johns Hopkins University Press, 1975), pp. 144-172).

13. José Antonio Maravall, El concepto de España en la Edad Media, 2d. ed. (Madrid: Instituto de Estudios Políticos, 1964), p. 48.

14. J. H. Elliott, Spain and Its World 1500-1700. Selected Essays, (New Haven: Yale University Press, 1989), pp. 103-106. As he describes the community understood as the patria, it "was founded on history, law and achievement, on the sharing of certain common experiences and certain common patterns of life and behaviour. As such, it was an ideal - indeed an idealized - entity, already perfect in itself ... The highest obligation incumbent upon its members was . . . to ensure that in due course it should be transmitted intact to their successors" (p. 106).

15. Ambrosio de Morales, Corónica general de España, vol. 4, (Madrid: 1791), p. 1.

16. Ibid., p. 18.

17. Kantorowicz, p. 304.

18. Ibid., p. 294.

19. "For between the generic communitas or universitas on the one hand, and the individual and material community of Bologna composed of mutable citizens and perishable buildings on the other hand, an entity which was immaterial and invariable, though not devoid of individuation, which existed (as it were) in some perpetual aevum, and which appropriately might have been called Bononitas or 'Bolognity,' had the lawyers not preferred to talk about the corporate universitas - that is, the juristic person or personified community - of Bologna. Nevertheless, that corporate, if incorporeal, Bononitas represented, like the angels, species and individuation at the same time" (Ibid., p. 303). 
20. Morales, p. 13.

21. Ibid., p. 14.

22. Ibid., p. 20.

23. Ibid., p. 21.

24. The unification of Portugal with Spain had been a continuous goal of the Hapsburgs throughout the century (see Manuel Fernández Alvarez, Política mundial de Carlos $V$ y Felipe II (Madrid: Consejo Superior de Investigaciones Científicos, 1966), pp. 252-253. Precedence for the self-destruction of an entire city is also set by the Vaceos, as mentioned briefly by Livy, which Morales describes as yet another "brava hazaña, de las que (como muchas veces en esta historia hemos visto) usaban los Españoles en sus desesperaciones" (35).

25. Morales, p. 39.

26. Ibid., p. 7.

27. "Lucio Floro dice que no había soldado Romano que osase esperar, en oyendo una voz de un Numantino, o en viéndole venir. Paulo Orosio cuenta, que estaba la fuerza Romana tan embotada, que no sabía soldado ninguno, afirmar los pies para no huir, ni asegurar el ánimo para esperar. Luego que veía el Romano al Español, se tenía por vencido, y en solo huir le parecía que estaba su remedio: que éstas son las palabras de aquel autor" (Morales, p. 27). It is important to note that Morales has elaborated upon Paulus Orosius' quote, which itself reads simply: "namque ubi copia pugnandi facta est, exercitus Romanus oppressus impetu Numantinorum terga conuertit" (Historiarum adversum paganos libri septem. In Paulo Orosio: su vida y sus obras, ed. Casimiro Torres Rodríguez (Santiago de Compostela: Fundación Pedro Barrie de la Maza Conde de Fenosa, 1985), p. 412.

28. Morales, p. 45.

29. Miguel Herrero García, Ideas de los españoles del siglo XVII, (Madrid: Gredos, 1966), pp. 59-66, 95-96.

30. Morales, p. 49.

31. Ibid., p. 48.

32. Torres Rodríguez, p. 416.

33. The unification of the kingdoms of Castille and Aragon and the forced conversion of Jews and Moslems that formed the basis of the creation of a Spanish nation by Ferdinand and Isabella did not meet with universal approval or take place peacefully. Most salient are the Comunero uprisings in Castille in the 1520 s and the various Morisco revolts. For an analysis that sees as a subtext for Cervantes' Numancia the siege of the Moriscos in Alpujarras by Don Juan de Austria (1570), see Alfredo Hermenegildo, La Numancia de Cervantes (Madrid: Biblioteca de Crítica Literaria, 1976), pp. 46-74.

34. Herrera himself admits that his tirade against the Italians is a digression. "Quiero discurrir aquí un poco, apártandome del intento, pues se ha ofrecido ocasión. Porque no sé qué ánimos se puedan hallar tan pacientes que toleren los oprobios y denuestos con que vituperan a los 
españoles los escritores de Italia. Antigua costumbre es suya, y heredada de los romanos, alabar con grandes exceso las hazatas de su gente..." (Fernando de Herrera, "Comentarios de Fernando de Herrera" in Garcilaso y sus comentaristas, ed. Antonio Gallego Morell (Madrid: Gredos, 1972, p. 552).

35. Herrera, p. 552.

36. Ibid., pp. 552-553.

37. "Y así volveré de principio a la antigua queja que tiene España, no común a la queja de las otras provincias sujetas al imperio de Roma, porque ninguna fue más tratada y conocida, ninguna más ocupada en la milica romana, ninguna más provechosa, o en riquezas, o en hombres belicosos y ejercitados en la guerra, y ninguna (si conviene decirse así) más ignorada de los historiadores romanos, que pasan sus hechos en tanto silencio que parece que nunca tuvieron noticia de ella, o que nunca crió ánimos valerosos y merecedores de gloria" (Herrera, p. 553).

38. Herrera, p. 553.

39. Ibid., pp. 553-554.

40. Ibid., p. 554.

41. Ibid., p. 553.

42. Ibid., p. 555.

43. J. B. Avalle-Arce, Nuevos deslindes cervantinos (Barcelona: Ariel, 1975), pp. 249-256. Quotes from the play come from Miguel de Saavedra Cervantes, "La Numancia." Diez Comedias del Siglo de Oro, eds. José Martel and Hymen Alpern, 2d. ed. (Prospect Heights, IL: Waveland Press, 1968).

44. StanislavZimic, "Visión política y moral de Cervantesen 'Numancia,"'Analescervantinos, 18 (1979-80), 107-150.

45. Marie Laffranque, "De l'histoire au mythe: à propos du 'siège de Numance' de Cervantès," Revue Philosophique de la France et de l'Étranger, 92 (1967), p. 284.

46. Ramón Menéndez Pidal, Idea imperial de Carlos V, 5th ed. (Madrid: Espasa-Calpe, 1963), p. 12.

47. Laffranque, p. 278.

48. Menéndez Pidal, pp. 18, 28-29.

49. As Joaquín Casalduero (Sentido y forma del teatro de Cervantes, Madrid: Gredos, 1967, p. 281) and Edward H. Friedman (The Unifying Concept: Approaches to the Structures of Cervantes' Comedias (York, SC: Spanish Literature Publications, 1981, p. 58) have observed, the tale centers around pagan values such as fame and resolves the issue of the pagan practices by neutralizing their representation with the thematic presentation of the Christian concept of life in death. I do not believe that the pre-Christian setting or the possible thematic content frees the playwright or the public from wrestling with such loaded moral issues as suicide and lack of mercy, not to mention the more lurid depictions of communication with the dead, invocation of spirits, and references to cannibalism. 
50. As Angelo J. DiSalvo points out, Don Quijote in his instructions to Sancho Panza concerning just government warns against corruption and self-interest (p. 55), and asserts that the role of the soldier is more important than that of the man of the letters in preserving the peace (p. 56), yet also recommends "the tempering of justice with compassion" ("Spanish Guide to Princes and the Political Theories in Don Quijote," Cervantes, 9:1 (Spring 1989), pp. 5456). Although it is always dangerous to consider Don Quijote's words an expression of Cervantes' thought, this description of the good and bad behavior in the man of war does align with the ambivalent character of Scipio, who is uncorrupted and selfless in his service to Rome, but also fails to act compassionately. According to Laffranque, the traditionally positive view of Scipio as a disinterested commander originates in particular with Polybius (pp. 276-7), whose work on military strategy served as textbooks for Renaissance officers (p. 283).

51. Jean Canavaggio has argued successfully that Cervantes has drawn most of his material for the play from Morales's account due to the coincidence of episodes (p. 40) and the inaccessibility of these episodes from the ancient sources in the vernacular in the sixteenthcentury. Cf Cervantès dramaturge: un théâtre à naître, (Paris: Presses Universitaires de France, 1977), pp. 40,77). As Hermenegildo points out (p. 29), I also believe that Cervantes had read Guevara's account.

52. Avalle-Arce, p. 104.

53. Augustine, The City of God, Trans. Marcus Dods (New York: Hafner, 1948), p. 35.

54. Paulus Orosius, pp. 406-407.

55. "Y pregunto yo a los Romanos: ¿por qué entregaron así a Mancino: pues que estando el exército todo a punto de ser muerto sin remedio, él le dió la vida con los conciertos de buena confederación, y sacó a salvo tantos millares de Romanos: y estando todas las fuerzas de su tierra en peligro de ser destruidas, las conservó enteras para tiempo de mejor oportunidad?" (Paulus Orosius, p. 25) Thus, Paulus Orosius continues his rhetorical interrogation of the Romans. As a follower of Augustine, Paulus Orosius's entire Historiarum adversum paganos libri septem represents a defense of Christianity from the detractors who blamed it for weakening the Roman empire, leading to the barbarian invasions. His rhetorical stance, then, is to show how the Roman empire was weakened by its own pagan values (p. 63). Thus, the virtue of the Numantians stands in contrast to the hard-hearted cruelty of the Romans.

56. Although it would be impossible to sustain that Cervantes himself was aware of the irony, the identity of Spain as Castille in the allegorical figure highlights the fictive character of the universitas as an entity immaterial and sempiternal but legally real based on the notion of the "perpetual 'identity despite change' of a community" (Kantorowicz, p. 302). Since the Iberia this figure purports to depict was and is varied and discontinuous, the creator of the figure is forced to choose one image, in this case that of the currently dominant Castille. Perhaps discord and division within an universitas are inevitable because that entity purports to stand for varied communities. 